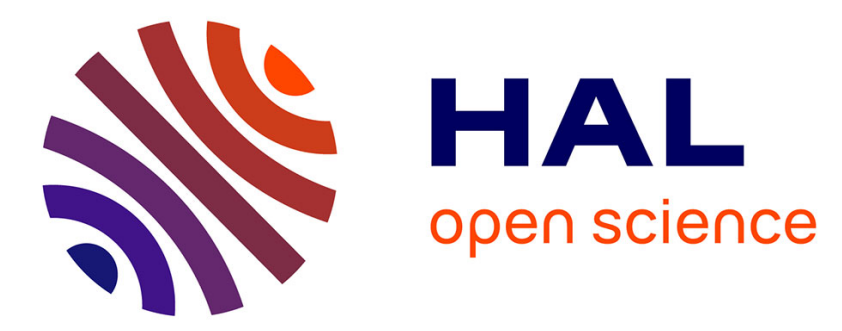

\title{
An example of large group drama and cross-year peer assessment for teaching science in higher education
}

Katherine Sloman, Richard Thompson

\section{To cite this version:}

Katherine Sloman, Richard Thompson. An example of large group drama and cross-year peer assessment for teaching science in higher education. International Journal of Science Education, 2009, 32 (14), pp.1877. 10.1080/09500690903229312 . hal-00531153

\section{HAL Id: hal-00531153 \\ https://hal.science/hal-00531153}

Submitted on 2 Nov 2010

HAL is a multi-disciplinary open access archive for the deposit and dissemination of scientific research documents, whether they are published or not. The documents may come from teaching and research institutions in France or abroad, or from public or private research centers.
L'archive ouverte pluridisciplinaire HAL, est destinée au dépôt et à la diffusion de documents scientifiques de niveau recherche, publiés ou non, émanant des établissements d'enseignement et de recherche français ou étrangers, des laboratoires publics ou privés. 


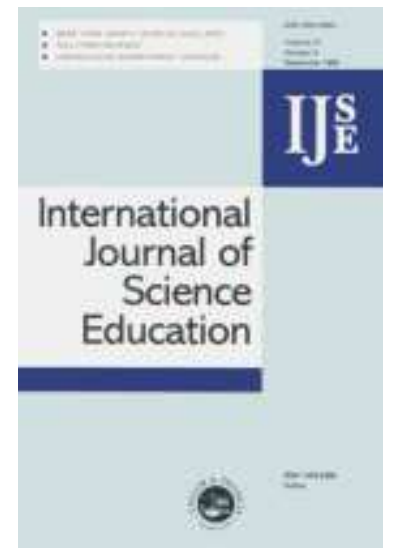

An example of large group drama and cross-year peer assessment for teaching science in higher education

\begin{tabular}{|r|l|}
\hline Journal: & International Journal of Science Education \\
\hline Manuscript ID: & TSED-2009-0125.R1 \\
\hline Manuscript Type: & Research Paper \\
\hline Keywords: & $\begin{array}{l}\text { assessment, learning environment, environmental education, } \\
\text { university, science education }\end{array}$ \\
\hline Keywords (user): & drama, peer assessment \\
\hline \multicolumn{2}{|l}{} \\
\hline
\end{tabular}

\section{S ScholaroNE \\ Manuscript Central}




\section{Abstract}

Undergraduate students spanning three years of a marine biology degree programme $(n=86)$ experienced a large-group drama aimed at allowing them to explore how scientific research is funded and the associated links between science and society. In the drama, year one students played the 'general public' who decided which environmental research areas should be prioritised for funding, year two students were the 'scientists' who had to prepare research proposals which they hoped to get funded and year three students were the 'research panel' who decided which proposals to fund with input from the priorities set by the 'general public'. The drama, therefore, included an element of cross-year peer assessment where level three students evaluated the research proposals prepared by the level two students. Questionnaires were distributed at the end of the activity to gather a) student perceptions on the cross-year nature of the exercise b) the use of peer assessment and c) their overall views on the drama. The students valued the opportunity to interact with their peers from other years of the degree programme and most were comfortable with the use of cross-year peer assessment. The majority of students felt that they had increased their knowledge of how research proposals are funded and the perceived benefits of the large group drama included increased critical thinking ability, confidence in presenting work to others and enhanced communication skills. Only one student did not strongly advocate the use of this large-group drama in subsequent years. 


\section{Large-Group Drama}

This study examined the usefulness of a large group drama in allowing undergraduate students to explore how science is funded within the UK funding system. It has been suggested that drama can be a successful vehicle to learn about science in the context of society, enhancing higher order learning skills and allowing students to explore attitudes and perceptions (Alrutz, 2004; Ødegaard, 2003). In addition, personal involvement in an issue is likely to be more meaningful than simply reviewing the situation impersonally from the outside (Bailey and Watson 1998). Drama provides a cooperative learning environment (Christofi and Davies 1991; Kase-Polinsini and Spector 1992) where students get to think and use science in a real situation (Sparks-Linfield 1996).

In our drama, distinct roles were played by three different year classes in a degree programme, B.Sc. Marine Biology at the University of Plymouth. Each role was designed to reflect the appropriate level of scientific knowledge for that particular year class and through the large group drama it was intended that each year class would develop a different set of skills and learning outcomes. The overall concept of the drama was that in groups, year two undergraduate students would play the role of researchers wishing to get their science funded and prior to the day of the drama were asked to prepare a funding application in the form of a poster. For the year two students $(n=32)$, this piece of work represented an assessed piece of coursework.

On the day of the drama, the year two students presented their posters during a two-hour lunchtime conference session and were required to verbally defend their work to students from years one and three. Year three students $(n=21)$ were asked to take the role of the 
scientific panel judging the funding proposals due to their greater level of scientific experience. Year one students $(n=32)$, at the start of their degree programme, were asked to input their views in the role of the educated general public as to which subject areas were most important to fund. The year one students were required to attend the large-group drama as a timetabled activity but the year three students were asked to attend the day voluntarily. We hoped that by utilising such dramatisation of the concepts involved in funding biological research within the UK, we would allow collaborative pursuit of goals (Catterall, 2007).

The year one students were four weeks into their degree programme and we envisaged that taking on a role as a year group would allow them to discuss and develop their attitudes and perceptions about science in society and how scientific research is funded as they became part of the academic community. We also wanted to allow them the opportunity to explore, in a safe environment, their abilities to make informed decisions about which areas of biology they believed were particularly important for funding allocation and to encourage them to think critically about the social consequences of scientific activities. Butler (1989) highlights that in using drama techniques it is important to be sensitive to the need of the students to have confidence and trust in the situation in order to engage appropriately with the activity. The role of the year two students was central to the drama and they were the only year group required to prepare work in advance. In presenting and defending their research proposals to the two other year classes we aimed, through the social nature of drama, to encourage them to think about ways of communicating their ideas to a mixed-ability audience and how they might foster understanding of their research proposals by their peers. In a study looking at the effectiveness of drama in teaching, Metcalfe et al. (1984) showed that students within an experimental group that were taught through drama, although they showed no greater ability 
in factual recall than a control group, developed a better ability to offer explanation and interpretation of concepts.

In casting the year three students in the role of the scientific panel, brought together to judge the funding proposals, we aimed to foster their critical thinking skills. Ødegaard (2003) argues that science education needs to offer students an insight into the value of critical reflections within science. One type of critical thinking highlighted by Bailin (1998) is to be able to think critically about the principles and criteria by which something is assessed. Critical thinking requires a level of background knowledge and we expected this of the year three students who would have gained an understanding of the principles by which scientific work is judged through previous feedback on their own scientific assessments. With the aim of giving them a sense of ownership of their role and also to promote this type of critical thinking we asked the year three students to develop their own criteria for evaluating the research proposals of the year two students.

\section{Peer Assessment}

Peer assessment is being increasingly utilised in higher education (Gatfield 1999) for a variety of reasons including the idea that it represents part of the preparation for life that a university education gives (Brown et al. 1997; Ellis 2001). There are many advantages of peer assessment including the opportunity to reflect on own performances (Dochy et al. 1999; Papinczak et al. 2007) and to develop critical reasoning skills (Falchikov 1986; Searby and Ewers 1997). Peer assessment may also stimulate subject matter discussions between students (Berg et al. 2006) and aid collaborative learning (Prins et al. 2005). However, asking students to evaluate the performance of peers can potentially have some shortcomings. In particular, 
students may be uncomfortable criticising friends and may be influenced by existing relationships within the cohort (Cheng and Warren 1997; Papinczak et al. 2007).

In our study, the evaluation of the year two research proposals by year three students allowed us to introduce an element of peer assessment which as defined by Topping's (1998) typology of peer assessment was between different years of study. Peer assessment in our drama differed from the majority of studies on peer assessment where assessment is conducted among students of the same year class. Here peer assessment was implemented across, not within, year classes. By employing cross-year peer assessment we attempted to minimise potential problems with students feeling uncomfortable criticising friends or colleagues within their own degree class. Particularly for the year three students (assessors), we hoped that this form of assessment would still foster critical thinking and reflection on their own assessment approaches. For the year two students (assessees), we envisaged that through the presentation of their work to year three students they would potentially invest greater effort into their work as noted in other types of peer-assessment (Pope 2005) and that they would also benefit from collaborative learning.

\section{Cross-Year Interaction}

Our drama involved a cross-year approach where all three years of a degree programme participated. We hoped that this would enable students to draw on the importance of 'communities of practice' in learning processes as an environment where novices can interact with the more expert (Lave and Wenger, 1990). The drama was located at the beginning of the academic year so as to maximise potential benefits of the peer-interaction for each of the year classes. First year students had just commenced their degree studies and as such were well placed to be comfortable acting as members of the general public. The year two students 
had recently completed a field course where they had been given guidance on how to implement a research project and communicate the outcomes; hence their role in the current drama was timely with their current studies. Year three students were already undertaking their final year independent research projects which require critical evaluation of existing scientific literature. Therefore, it was hoped that all years would feel comfortable with the roles they were allocated, an aspect important to the success of drama activities (Hargreaves and Hadlow, 1997). Additionally, by participating in this cross-year drama and interacting with more experienced students on the same degree programme, we anticipated that the year one and two students would gain a clearer picture of the learning experience in the three years ahead of them and that this would aid their learning progression (Catterall, 2007).

\section{Outline of the drama}

The drama was realistically grounded in current research funding scenarios and here was specifically aligned with one of the UK's major research councils, the Natural Environment Research Council (NERC). The drama was facilitated by two members of academic staff and a representative from NERC to help students connect to the reality of the roles they were playing. Prior to the main drama, in small groups (each with two to four students) the level two students were given two weeks to develop a research proposal that they hoped to get funded. They were given a maximum hypothetical amount of money that they could apply for and a timescale in which the proposal would have to be carried out if it was funded. Although in this specific drama there was no funding available, various small grants and funds are available to students at this stage in their education and so the event had a clear grounding in reality. The students were asked to prepare their proposals in the form of an A0 poster and were asked to clearly identify on the poster: 
a) their research question.

b) the necessary background information to support this question.

c) the appropriate methods/experimental design for achieving their research proposal.

d) how their research proposal related to current research council funding priorities.

At the time of the drama, NERC had seven funding priorities highlighted within their remit. These were (i) biodiversity, (ii) climate system, (iii) sustainable use of natural resources, (iv) environment, pollution and human health, (v) earth system science, (vi) natural hazards, (vii) technologies. Of these, we felt the first four were the most appropriate to the degree programme involved and that the students would possess adequate background knowledge of these topics. Therefore, for part (d) of their poster, the year two students were asked to tailor their proposal towards at least one of these four priorities. Although the priorities we used were specific to NERC, they represent current global priorities in biological sciences. The content of our drama was specific to our discipline; however, it could easily be adapted across a range of disciplines to match research priorities in a whole range of different subject areas. During the two weeks when the students were preparing their posters, they were given access to a technician who provided help in using PowerPoint to create a poster and in getting their poster professionally printed.

\section{Implementation}

The day of the drama began in the morning with a plenary briefing session for all three years facilitated by the NERC representative. Students were provided with an overview of how science is funded in the UK; where the money comes from and how decisions on its allocation are reached. They were then guided through the structure of the day and the parts they would be playing. Each student was given a timetable of the sessions they needed to attend and were 
provided with a discussion area to be used during non-timetabled events where tea and coffee were provided.

Year two students were allocated their own stand in the conference hall and were allowed to display their work and prepare for the lunchtime conference. Year one and year three students were then briefed on their respective roles in separate workshops. In the year one workshop, students were given the opportunity to debate the science issues facing the UK today and to decide on their funding priorities as members of the general public. As a conclusion to this debate, they were given the four research council priorities which the year two students had already been given as part of their initial brief, two weeks earlier. Year one students then ranked these topics as a class in order of their perceived importance to the general public. The ranking was later used to help decide which research proposals to fund. In the year three workshop, students debated what they considered to be good science, and how they might evaluate this within a research proposal. Facilitated by staff, these discussions were encapsulated as a research grant assessment form that could be used to generate a numerical score. In peer assessment, it is considered important that students are involved in the criteria setting to allow full understanding of the criteria which they will use to evaluate other students' work (Sivan, 2000). Students from years one and three were then brought together and placed into 'research evaluation' groups consisting of two students from each year.

The two-hour conference session then commenced and research evaluation groups circulated around the year two stands. During this exercise, level one students were mainly present in an observational role while level three students acquired information against the criteria on their research grant assessment form for each proposal, based on the poster and its oral defence. Each research evaluation group was required to complete an assessment form for every poster but were allocated two specific proposals that they would have to discuss in detail at the 
a) is the proposal broadly feasible within budget?

b) is there a clear question with methods appropriate to the hypothesis?

c) is the wider significance and originality included?

d) is there evidence of understanding of the relevant background?

e) is there clarity of presentation?

On the assessment form, each evaluation group could comment on these points and then generate a score for the proposal on a scale of 1 to 10 where 1 was unfundable and 10 was excellent. They finally needed to grade the proposal according to whether it fitted with the four priority topics that the year two students were given where (A) was completely aligned with NERC priorities, (B) was aligned with NERC priorities and (C) was not aligned with NERC priorities.

Following the conference session, a confidential panel meeting was convened for year three students only. The panel was chaired by the representative from NERC. Funding proposals 
were taken in turn and as each was tabled, the two groups that had prepared detailed evaluations were initially asked to present their scores and then debate the strengths and weaknesses of the proposal. The remaining groups were then allowed to contribute to the discussion of that research proposal in order to reach a representative final score. This process identified proposals which were eligible for funding based on their scientific merits and those that were not eligible. The year three students were then provided with the information on how the year one students had ranked the four NERC funding priorities and were also informed that there were sufficient funds to support two proposals. The priorities identified by the year one students earlier in the day were then used to rank those proposals which the panel had deemed eligible for funding based on scientific merit. The two highest ranking proposals in terms of scientific merit and priorities for funding were highlighted as successful proposals. On the day, evaluation by the year three students with input regarding funding priorities from year one students were the only contributing factors to the final ranking of the grants. Subsequent to the day of the drama, two members of academic staff marked the posters in accordance with their university's School Marking Criteria, and used the ranks generated by the peer evaluation to contribute $10 \%$ of the final mark. Overall, there was strong agreement between the marks of the academics and those from the peer assessment toward both the top and the bottom of the marks distribution.

The day was concluded with a plenary session attended by all three year classes where the outcomes of the research funding panel were announced by the NERC representative. The key events of the day were summarised and discussed across all activities, and prizes were awarded to the two successful year two teams.

\section{Evaluation}




\section{Questionnaire Results}

Of the 86 students involved in the drama, 85 students completed the questionnaire. These were 21 level three students (8 male, 13 female, ranging in age from 20-25), 32 level two students (10 male, 22 female, ranging in age from 19-32) and 32 level one students (14 male, 18 female, ranging in age from 18-28).

\section{Student Perceptions of the Large Group Drama}

It was evident during our observation of the year three panel meeting, that the drama had promoted substantial critical thinking. One type of critical thinking challenge is to think critically about the criteria used in evaluation (Bailin, 1998). Feedback indicated that the drama had encouraged year three students to critically think about their own work and to reflect on how best to approach their own ongoing final year research projects. The ability to critically reflect on their own work is an improved learning benefit of drama also highlighted by Dochy et al. (1999). One student reflected that 'It was a good experience and helps [you] to be more critical of your own work'. Most level three students thought that the drama had improved their ability to debate opinions and make decisions and all thought that their ability 
to critique scientific research had improved. Comments from the students included

'Evaluating others' work and discussing it helped see other views clearly leading to a deeper understanding', and 'I've been able to see how you would critically approach a project and will therefore be better able to see weaknesses in my own projects'; the first comment here illustrating that drama can promote collaborative learning (Kase-Polinsini and Spector 1992)

The presence of a NERC representative and the use of a conference-style drama appeared to enhance the student experience and many students recognised that the drama was set as close as possible to reality which we had intended in order to allow the students to enter the exercise as fully as possible (Moss, 2000). Comments from level three students regarding the conference-style of the drama included 'Good experience of conference environment for all years' and from the year two students 'It was a good way to meet other students and represents a real conference giving us an idea of what to expect should we enter research careers' and '(I feel) more confident about presentations and explaining work orally, writing scientifically and the conference environment and how it works'. In particular, the third year students felt that the presence of the NERC representative added realism to the drama reflecting that 'She made the situation realistic', 'It was realistic and gave an idea of how things are done in the professional world' and 'Made the council meeting more official as it showed what it would really be like'. Year one students thought that she gave 'a more important and official feel to the day'. On the day it was obvious that the majority of the students really entered into the exercise. One example of this is that the students themselves, instigated before the event by the level two students, chose a smart dress code and one student commented 'It was an enjoyable day, I think the smart dress code helped'.

Our initial aim in running this large-group drama was to allow undergraduate students to explore how science is funded within the UK funding system. There were numerous 
comments within the questionnaires highlighting that the students perceived they had learnt a lot about how to get their research funded. The year one students were still quite early on in their careers to be contemplating applying for research funding and yet they still grasped how important it was to understand how science is funded. Comments included ' $I$ was able to understand what sort of things would get funded and why', 'I feel a lot more confident about entering the scientific career track when I leave university' and 'I now understand more about the funding and other opportunities available'. For the year two students who had experienced writing their own proposals, they felt that they had learnt a lot about how research is funded and how this might apply outside of their academic studies. One student wrote '[I gained] an insight into what is involved and what a research scientist does and challenges faced' and another said 'It was a good preparation to show what is involved in a much larger proposal for the real world'. Comments from the level three students, those closest to embarking on their own careers, suggested that they had begun to perceive how competitive and challenging applying for research can be. Previous studies have also found that drama helps students actually see the influence of scientific debate within the real world (Duveen and Solomon 1994). For example, some of the level three students reflected that '[The day] gave insight into the competitiveness of research proposals', 'I have learnt how hard it is to get funding and how dedicated you have to be' and '[I] now know how hard it is to get funding and have a better knowledge of why funding might be approved/refused'.

\section{Student Perceptions of the Peer Assessment}

Peer assessment in the current drama differed from the majority of studies on peer assessment where assessment is conducted among students of the same year class. Here assessment was conducted between different years of study and was compulsory for assessees (year two) but not assessors (year three), who attended the day voluntarily. Although, year one students 
participated in the conference session, they were not directly involved in the final ranking of the proposals. Peer discussion about the proposals was face to face, although feedback and discussion was not. Peer evaluation was the only contributing factor to the final ranking of the grants on the day and these ranks were subsequently used to inform staff assessment of the proposals which generated the final academic grades. Year two students were aware that the final academic marking would be primarily based upon staff marking and this perhaps eased the stress which has been associated with peer assessment (Pope, 2005). Other studies on peer assessment have used normalisation of marks to remove any inherent problems with studentgenerated marks (Li, 2001). It has also been suggested that peer assessment may be considered a primary tool for learning rather than a tool of summative assessment (Brown et al. 1997).

In general, year two students did not feel uncomfortable in having their work evaluated by their peers (Figure 2a) and many felt that they gained from this experience. Comments included 'It was great to be able to answer questions from $3^{\text {rd }}$ year students as it was nice to share my knowledge with them even though technically they are more qualified than me', 'It was extremely useful to have questions to answer especially since I had no idea what they could be. It's been a really useful experience' and 'It's good to have students look at the work as opposed to just staff [as this equals] different opinions and questions'. Due to the conference-style nature of our large group drama, research evaluation groups of years one and three students circulated around the year two poster displays. It is clear from the comments on peer assessment that there was a variety of approaches used by the evaluation groups meaning that some students had mixed perceptions of the peer assessment. For example, one student wrote 'Some comments were useful constructive criticism; however some seemed as though they were questioning just to catch you out as opposed to being focussed on the investigation' 
and another wrote 'Most of the $1^{\text {st }}$ and $3^{\text {rd }}$ years provided good criticism and questions but many weren't allowing you to explain your point'.

Two year two students perceived the aspect of peer assessment as purely negative. One said ' 3 rd years didn't have many positive things to say. They focussed too much on the negatives which made it seem as though they were not interested in our project, just criticising it' and another that 'It was a lot of negative critical feedback hardly any positive from $1^{\text {st }}$ and $3^{\text {rd }}$ years, off-putting and down heartening. Didn't get on with my group members which affected my reasoning when doing the poster'. In the latter case, social interactions within the year two group appear to have clouded the day in general and these emotions may well have impacted on the perception of peer assessment. Although these comments are in the minority, it is clear that there is a difficult balance between asking students to critically review the work of others and being able to communicate criticism constructively. Here cross-year peer assessment created the potential problem that peer assessment was not reciprocal i.e. the assessment of year two work by year three students was unidirectional. Although critical discussion of the research proposals occurred behind closed doors in a research panel, the face-to-face interaction during the poster conference allowed the opportunity for negative critical feedback to occur. Throughout their degree programme, the level three students rarely encounter peer assessment and are not given much opportunity to formally assess other pieces of science. Indeed one level three student wrote that they appreciated the "chance to critically review studies - something that I feel is lacking in other teaching through the course but is obviously important'. We feel that a useful addition to the large-group drama would be a session in the initial workshop for level three students on how to communicate critical comments in a positive and useful way and to give constructive feedback on scientific research. 
Broadly speaking year three students did not feel uncomfortable in conducting these evaluations (Figure 2b) with comments such as 'Even if it was hard it is a great opportunity to use the different skills we have'. Several students obviously valued the fact that the main deliberations about the research proposals were behind closed doors with comments like 'In some cases [I felt uncomfortable] but generally it wasn't too bad because it was a confidential meeting with peers'. One student indicated that the initial thought of critiquing the level two students work was daunting, but that this changed during the course of the day ' $I$ found this exercise very helpful - I started the day feeling I may not know enough to evaluate but this changed while doing it' and only one student highlighted that they were uncomfortable with the cross-year peer assessment saying 'I felt a little judgemental and thought that I could not have done much better than the $2^{\text {nd }}$ years did' a feeling that has been recorded in previous studies (Orsmond and Merry, 1996).

\section{Student Perceptions of the Cross-Year Approach}

Responses from the student perception questionnaires suggested that the cross-year element was a positive aspect of the drama. Interactions either with peers in year classes above, below, or in the case of level two students both, were considered to be beneficial (Figure 1).

Supporting written commentaries from the students relating to this question gave a further insight into their responses. One of the main benefits perceived by the year one students was anticipatory; looking ahead to where they would be and the quality of work they would be producing in a year's time. Comments included 'It gave me a bit of an idea of what to expect in the future, it was also beneficial to see the high quality of work produced by those who have only done one year (i.e. level two students) so far on the course' and 'Good experience to see what scientific methods we are going to be using and how these research projects are set up. It was also good to make new friends and get advice from the $2^{\text {nd }}$ and $3^{\text {rd }}$ years'. For 
most, this was extremely positive allowing a much greater appreciation of the quality of work which they could achieve during their degree programme. For example, one student wrote 'As a first year student learning what was expected of the presentation and the questions being asked was a good experience'. Year one students also valued the opportunity for scientific discussion with other year classes. One student wrote 'It was interesting to mix opinions with older students as they had different viewpoints' highlighting the benefits the drama provided for collaborative learning and in creating an environment where novices can interact with the more expert (Lave and Wenger, 1990). As a consequence we hope that the students should be able to develop linkages between different aspects of their academic study as they progress through the degree programme rather than purely retrospectively. For some students these future standards were perceived as challenging reflected in the comment 'I personally wouldn't feel comfortable in the position of the $2^{\text {nd }}$ years. But I can see that it is a good experience in the future'. So, nonetheless, this student appeared to see the benefits of the large group drama for their future career development.

Year two students also felt they benefited from being able to look ahead explaining that ' $I t$ was good to hear about what's ahead of me', 'It's been useful for me to ask questions about the $3^{\text {rd }}$ year and what it is like. It's also been fun to pass on experience of the $1^{\text {st }}$ year' and 'It was interesting to see the level of knowledge of those one year ahead of us to see where we will be in 12 months'. In most cases the level two students actually took this a step beyond the level one students, and identified ways in which the day's activities would directly enhance their future studies. For example, one student wrote 'It's a good way to develop your presentation skills and your ability to further your skills in research development which will be useful for later life and particularly $3^{\text {rd }}$ year'. Most level two students valued the opportunity to present their work to peers above and below them in the degree programme as 
they recognised the importance of being able to communicate their science to a diverse audience which was reflected in the comments such as 'Having questions from people who maybe look at things from a different perspective was good' and 'It made me understand how difficult it can be to communicate how important an issue may be to people who have no previous experience'. Again, the drama appeared to create clear benefits of cross-peer interaction and the ability to bring together students with a varying range of expertise. For year three students, the drama did not offer the opportunity to look ahead in terms of their degree programme; however it did allow them to reflect on their educational journey and how much they had learnt in the previous two years allowing 'recognition of how our knowledge has advanced through the course'.

\section{Conclusions}

When asked the question, should this event be repeated in subsequent years, we received an overwhelming positive response (Figure 3). We believe that integration of drama, like the one used here, into the science curriculum in higher education could have a positive impact, with a larger proportion of graduate students leaving university better informed about how scientific research is funded and the links between science and society. As ambassadors for their discipline, whether or not these students go on to become practicing scientists, policy makers, or informed members of the general public in an alternative occupation, consideration of these ideas during their studies may pave the way for greater understanding in the future.

\section{Acknowledgements}

We thank Poppy Leeder from the Natural Environment Research Council for helping to facilitate the drama and John I. Spicer for constructive advice. Stefanie Broszeit, Piero Calosi and Mal Jones are thanked for their help on the day. Thanks also to Tony Harland for 


\section{References}

Alrutz, M. (2004). Granting science a dramatic licence: exploring a $4^{\text {th }}$ grade science classroom and the possibilities for integrating drama. Teaching Artist Journal, 2, 31-39.

Bailey, S., \& Watson, R. (1998). Establishing basic ecological understanding in younger pupils: a pilot evaluation of a strategy based on drama/role play. International Journal of Science Education, 20, 139-152.

Bailin, S. (1998). Critical thinking and drama education. Research in Drama Education, 3, 145-153.

Berg, I. van den, Wilfried, A., \& Pilot, A. (2006). Peer assessment in university teaching: evaluating seven course designs. Assessment \& Evaluation in Higher Education, 31, 19-36.

Brown, G., Bull, J., \& Pendlebury, M. (1997). Assessing Student Learning in Higher Education. London, Routledge. 317 pp.

Butler, J.E. (1989). Science learning and drama processes. Science Education, 73, 569-579.

Catterall, J.S. (2007). Enhancing peer conflict resolution skills through drama: an experimental study. Research in Drama Education, 12, 163-178.

Cheng, W., \& Warren, M. (1997). Having second thoughts: Student perceptions before and after a peer assessment exercise. Studies in Higher Education, 22, 233-239. 
Christofi,C., \& Davies, M. (1991). Science through drama. Education in Science, 141, 28-29.

Dochy, F., Segers, M., \& Sluijsmans, D. (1999). The use of self-, peer, and co-assessment in higher education: A review. Studies in Higher Education, 24, 331-350.

Duveen, J. \& Solomon, J. (1994). The great evolution trial: use of role-play in the classroom. Journal of Research in Science Teaching, 31, 575-582.

Ellis, G. (2001). Looking at ourselves - self-assessment and peer assessment: practice examples from New Zealand. Reflective Practice, 2, 289-302.

Falchikov, N. (1986). Product comparisons and process benefits of collaborative peer group and self assessments. Assessment \& Evaluation in Higher Education, 11, 60-69.

Gatfield, T. (1999). Examining student satisfaction with group projects and peer assessment. Assessment \& Evaluation in Higher Education, 24, 365-377.

Hargreaves, R., \& Hadlow, J. (1997). Role play in social work education: process and framework for a constructive and focused approach. Social Work Education, 16, 61-73.

Kase-Polisini, J. \& Spector, B. (1992). Improvised drama: A tool for teaching science. Youth Theatre Journal, 7, 15-19.

Lave, J., \& Wenger, E. (1990). Situated Learning: legitimate peripheral participation. Cambridge, Cambridge University Press.

Li, L.K.Y. (2001). Some refinements on peer assessment of group projects. Assessment \& Evaluation in Higher Education, 26, 5-18. 
Moss, B. (2000). The use of large-group role-play techniques in social work education. Social Work Education, 19, 471-483.

Orsmond, P., \& Merry, S. (1996). The importance of marking criteria in the use of peer assessment. Assessment and Evaluation in Higher Education, 21, 239-250.

Ødegaard, M. (2003). Dramatic science. A critical review of drama in science education. Studies in Science Education, 39, 75-102.

Papinczak, T., Young, L., \& Groves, M. (2007). Peer assessment in problem-based learning: A qualitative study. Advances in Health Sciences Education, 12, 169-185.

Pope, N.K.LI. (2005). The impact of stress in self- and peer assessment. Assessment and Evaluation in Higher Education, 30, 51-63.

Prins, F.J., Sluijsmans, D.M.A., Kirschner, P.A., \& Strijobs, J.-W. (2005). Formative peer assessment in a CSCL environment: a case study. Assessment \& Evaluation in Higher Education, 30, 417-444.

Metcalfe, R.J.A., Abbott, S., Bray, P., Exley, J., \& Wisnia, D. (1984). Teaching science through drama: an empirical investigation. Research in Science and Technological Education, $2,77-81$.

Searby, M., \& Ewers, T. (1997). An evaluation of the use of peer assessment in higher education: A case study in the school of music, Kingston University. Assessment and Evaluation in Higher Education, 22, 371-383.

Sparks Linfield, R. (1996). Can scientific understanding be assessed through drama? Primary Science Review, 45, 4-5. 
Sivan, A. (2000). The implementation of peer assessment: an action research approach. Assessment in Education, 7, 193-213.

Topping, K. (1998). Peer assessment between students in colleges and universities. Review of Educational Research, 68, 249-276.

Figure Legends

Figure 1: Responses to the statement: 'I have benefited from the opportunity to interact with students from a) year classes above me (answers from $1^{\text {st }}$ and $2^{\text {nd }}$ years ONLY); b) year classes below me (answers from $2^{\text {nd }}$ and $3^{\text {rd }}$ years ONLY)'. 1 = Disagree Strongly, $2=$ Disagree, $3=$ Neither agree nor disagree, $4=$ Agree and $5=$ Agree Strongly.

Figure 2: Responses to the statement: 'I felt uncomfortable by a) having my work evaluated by other students (question for $2^{\text {nd }}$ years ONLY); b) evaluating the work of other students (question for $3^{\text {rd }}$ years ONLY)'. 1 = Disagree Strongly, $2=$ Disagree, $3=$ Neither agree nor disagree, $4=$ Agree and $5=$ Agree Strongly.

Figure 3: Responses to the statement: 'This exercise should be repeated in subsequent years'. 1 = Disagree Strongly, 2 = Disagree, $3=$ Neither agree nor disagree, $4=$ Agree and $5=$ Agree Strongly. 
Figure 1
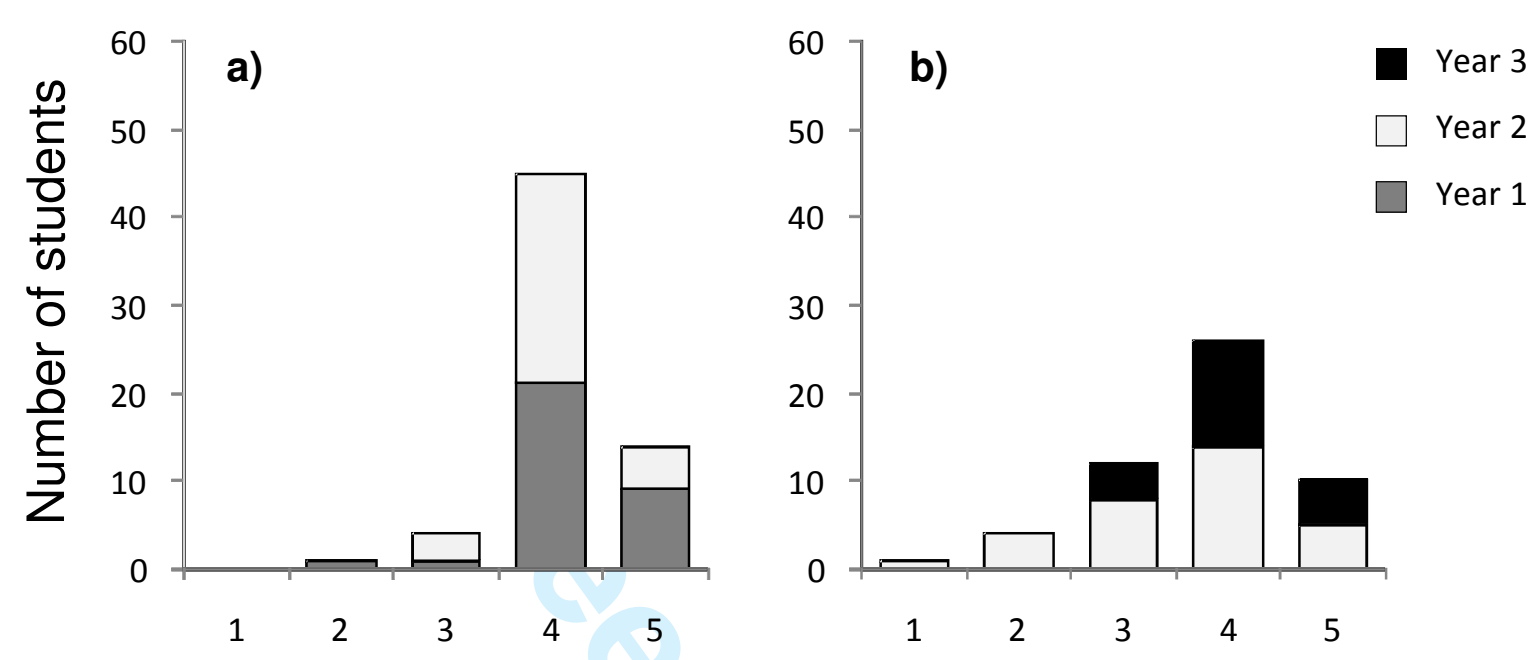
Figure 2
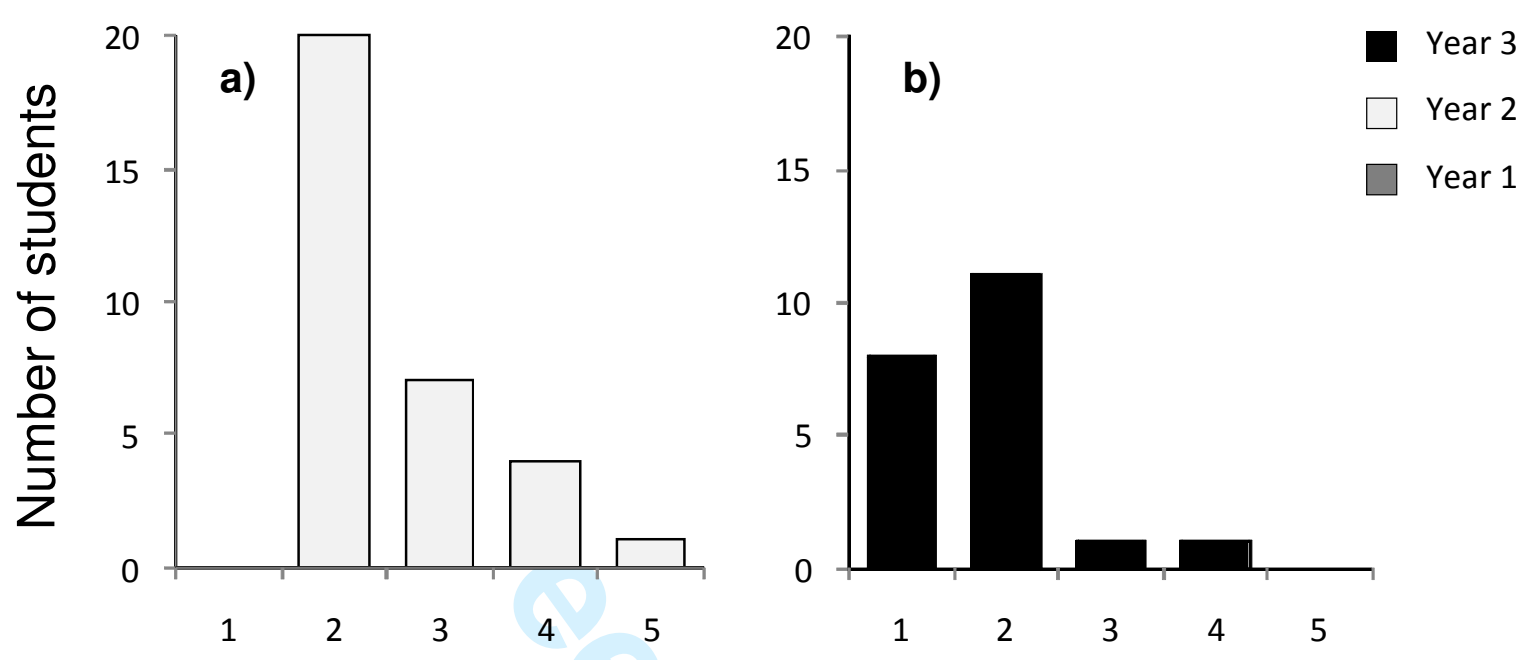
Figure 3

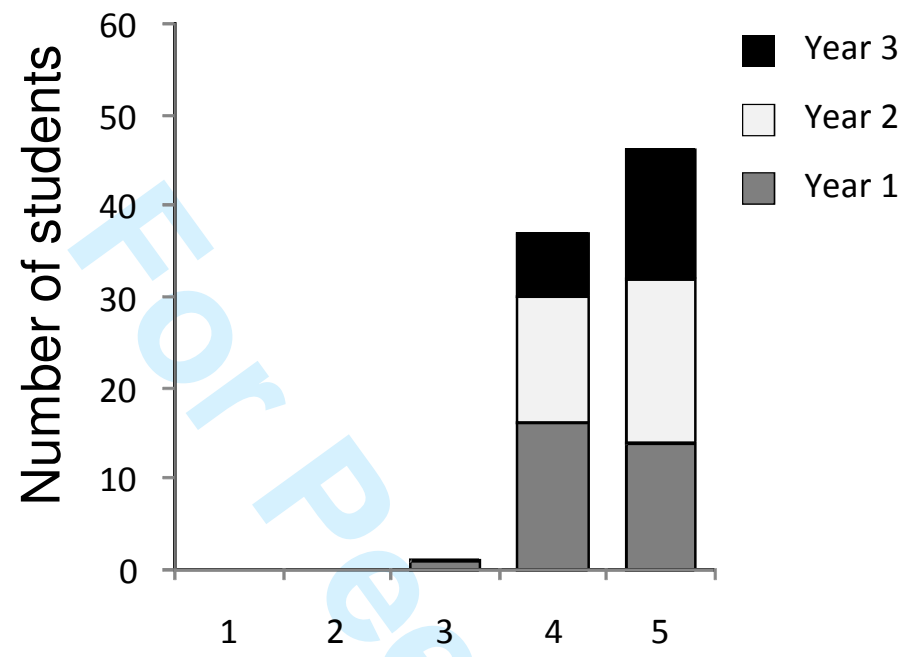


Appendix 1

\section{Questionnaire - Marine Biology Science and Society Workshop}

NB 1) There are no right or wrong answers. 2) This questionnaire will not influence any of your marks. 3) Please circle the responses that most accurately reflect your opinion on the following statements. 4) Please also add further explanations to your answers.

1) I have benefited from the opportunity to interact with students from

a) year classes above me (answers from $1^{\text {st }}$ and $2^{\text {nd }}$ years ONLY)

\begin{tabular}{|c|c|c|c|c|}
\hline $\begin{array}{c}\text { Disagree } \\
\text { Strongly }\end{array}$ & Disagree & $\begin{array}{c}\text { Neither agree nor } \\
\text { disagree }\end{array}$ & Agree & $\begin{array}{c}\text { Agree } \\
\text { strongly }\end{array}$ \\
\hline
\end{tabular}

Please explain

b) year classes below me (answers from $2^{\text {nd }}$ and $3^{\text {rd }}$ years ONLY)

\begin{tabular}{|c|c|c|c|c|}
\hline $\begin{array}{c}\text { Disagree } \\
\text { Strongly }\end{array}$ & Disagree & $\begin{array}{c}\text { Neither agree nor } \\
\text { disagree }\end{array}$ & Agree & $\begin{array}{c}\text { Agree } \\
\text { strongly }\end{array}$ \\
\hline
\end{tabular}

Please explain

2) My abilities in the following skills have improved as a result of this workshop (please circle yes OR no)

\begin{tabular}{|l|l|l|}
\hline teamwork & yes & no \\
\hline Debating opinions & yes & no \\
\hline Decision making & yes & no \\
\hline Evaluating scientific research & yes & no \\
\hline Communicating my work to a scientific audience & yes & no \\
\hline Communicating my work to the general public & yes & no \\
\hline
\end{tabular}

3) The presence of a representative from the Natural Environment Research Council added realism to today's exercise please answer yes or no and if possible explain your answer

Yes / no

4) I believe this workshop has broadened my understanding of the role of scientists in society.

\begin{tabular}{|c|c|c|c|c|}
\hline $\begin{array}{c}\text { Disagree } \\
\text { Strongly }\end{array}$ & Disagree & $\begin{array}{c}\text { Neither agree nor } \\
\text { disagree }\end{array}$ & Agree & $\begin{array}{c}\text { Agree } \\
\text { strongly }\end{array}$ \\
\hline
\end{tabular}

Please explain 
5) I believe this workshop has broadened my understanding of how society could influence UK science priorities.

\begin{tabular}{|c|c|c|c|c|}
\hline $\begin{array}{c}\text { Disagree } \\
\text { Strongly }\end{array}$ & Disagree & $\begin{array}{c}\text { Neither agree nor } \\
\text { disagree }\end{array}$ & Agree & $\begin{array}{c}\text { Agree } \\
\text { strongly }\end{array}$ \\
\hline
\end{tabular}

Please explain

6) I felt uncomfortable by

a) having my work evaluated by other students (question for $2^{\text {nd }}$ years only)

\begin{tabular}{|c|c|c|c|c|}
\hline $\begin{array}{l}\text { Disagree } \\
\text { Strongly }\end{array}$ & Disagree & $\begin{array}{c}\text { Neither agree nor } \\
\text { disagree }\end{array}$ & Agree & $\begin{array}{c}\text { Agree } \\
\text { strongly }\end{array}$ \\
\hline
\end{tabular}

Please explain

b) evaluating the work of other students (question for 3rd years only)

\begin{tabular}{|c|c|c|c|c|}
\hline $\begin{array}{c}\text { Disagree } \\
\text { Strongly }\end{array}$ & Disagree & $\begin{array}{c}\text { Neither agree nor } \\
\text { disagree }\end{array}$ & Agree & $\begin{array}{c}\text { Agree } \\
\text { strongly }\end{array}$ \\
\hline
\end{tabular}

Please explain

7) This exercise should be repeated in subsequent years

\begin{tabular}{|c|c|c|c|c|}
\hline $\begin{array}{c}\text { Disagree } \\
\text { Strongly }\end{array}$ & Disagree & $\begin{array}{c}\text { Neither agree nor } \\
\text { disagree }\end{array}$ & Agree & $\begin{array}{c}\text { Agree } \\
\text { strongly }\end{array}$ \\
\hline
\end{tabular}

Please explain

8) What was the most valuable element of the day in relation to

a) Your undergraduate studies

b) Your future career 
9) Any additional comments

10) Which year of study are you in? $\quad 1^{\text {st }} \mathrm{yr} \quad 2^{\text {nd }} \mathrm{yr} \quad 3^{\text {rd }} \mathrm{yr}$ (please circle)

Optional additional questions that would be valuable to the research

11) What is your gender? Male

Female

(please circle)

12) What is your age?

If you would be prepared to be involved in a related follow-up study please provide your contact details (optional) 